\title{
Post-Acquisition Strategies of Emerging Market Internationalizing Enterprises: The State of the Art in Research and Future Research Directions
}

\author{
Attila Yaprak, Mehmet Demirbag and Geoffrey Wood
}

A string of high profile takeovers of established Western firms by Emerging Market Multinational Enterprises (EMNNEs) has led to increasing interest in the latters' agendas, strategies and impact. Within just a few decades, some of these EMMNEs, for example Tata, Haier, Embraer, Gazprom, MTel and Arcelik, have become leading players in their respective sectors; at the same time, their rise and growth has in part reflected the consequences of very different institutional regimes and organizational histories to their Western counterparts (Ramamurti and Singh 2009; Khanna and Palepu 2010; Chattopadhyay, Batra, and Ozsomer 2012; Demirbag and Yaprak 2015).

This transformation has been a function of at least two intertwined forces. First, many emerging markets moved from autarchic, inward-orientated industrialization policies to a focus on export-led growth (Brand and Thun 2016; Rodrik 2016). Although not all succeeded in this transition, widespread reductions in domestic protectionism forced many nescient and existing MNEs to look abroad as a means of securing growth and economies of scale (Rodrik 2016). More outward looking foreign policies by home countries opened up new opportunities for overseas acquisitions (Peng et al. 2008; Luo and Tung 2007; Demirbag, Tatoglu and Glaister, 2009 and 2010). Many emerging markets faced challenges in sustaining national education training and skills development systems in the face of neo-liberal reforms. This increased pragmatism and liberal reforms, in turn, enabled a number of emerging markets from South Africa to China to properly utilize domestic human and financial capital, providing a further impetus for growth abroad. In essence, EMMNEs' growth abroad was driven by and facilitated through political and economic reform at home (Luo and Tung 2018).

If the first driver of overseas expansion was external to the firm, the second was internal. Experience of navigating institutional complexities at home made entry into other emerging markets with uneven or poorly coupled institutions less daunting (Yiu et al. 2007; Luo and Tung 2018). A combination of inexpensive but skilled managerial and labour pools provided the basis of capabilities for moving up value chains; this could now be supplemented through the acquisition of technologies through the acquisition of firms in mature markets (Jha et al. 2015). Finally, the risk of instability or even expropriation at home made acquisitions in mature markets more attractive. Although this was most pronounced in the case of Russian MNEs, similar concerns motivated even the more conservative MNEs to expand abroad (Wood 2015). 
Yet, EMMNEs also possessed competitive disadvantages as they expanded abroad, even with new-found confidence. Among these were liabilities of foreignness, often caused by their poor but often undeserved images of countries of origin, inefficiencies in diffusing know-how across their expanding networks, and the challenges they faced in their collaborative ventures in realizing the marginal gains they sought as rapidly as they would have liked. This led them to pursue cross-border mergers and acquisitions (CBMAs) as preferred entry modes as they discovered that these can provide rapid but efficient routes to accessing knowledge from their counterparts abroad, internalize these more proficiently, and appropriate them more resourcefully across their increasingly expanding worldwide networks.

As they internationalized through CBMAs, however, EMMNEs faced new, post-acquisition, challenges. First, they discovered that their efforts at value generation capability building and diffusion through CBMAs could lead to resource dilution and managerial inattention to other, equally demanding, business problems. They also found that their efforts at gaining wider geographic presence and increased profit generation involved operational and economic tradeoffs that were difficult to manage. They also faced the risk of anti-FDI protectionism, most notably with the populist drifts associated with calls to limit foreign takeovers of key domestic industries in the United States and other developed countries (c.f. Cumming et al. 2017). Finally, they realized that the absorption of knowledge from affiliates abroad was a difficult and time-consuming process that required a learning organization mindset and a corporate culture that would foster wiser and swifter absorption and appropriation of what is learned through CBMAs (Contractor, Kumar, Kundu, and Pederson 2010).

EMMNEs' efforts at resolving these tradeoffs spawned scholarly attention on these issues during the past decade or so: studies focused on the factors that foster CBMAs, post-acquisition strategies that firms follow as they internationalize, capability transfer mechanisms and knowledge flows, reverse knowledge flows from acquired subsidiaries to parent firms, CBMA performance outcomes and their success factors, and the roles of such strategic capabilities as entrepreneurship, absorptive capacity building, social integration, strategic agility, human resource configurations, and corporate culture on CBMA performance outcomes (Ahammad et al. 2016).

Yet, while enhancing our understanding of these issues in the context of CBMAs in general and EMMNEs' CBMAs more specifically, these studies have often focused on single firms and regions, leading to a somewhat fragmented picture, underscoring the need for a literature inventory and a prospective look forward. The purpose of this introductory article to the special issue of this journal is to help address this need by taking stock of the current literature with studies we selected to include in this volume, painting a more synthesized picture of that literature's landscape, and forwarding questions for future research to enhance understanding on this topic. In a later section, we present an overview of the 
contributions that we selected to appear in this special issue to fuel scholarly discussion of the questions raised in these papers. We now discuss the principal issues that occupy this landscape.

\section{Why do firms form CBMAs?}

Goedhart, Kohler, and Wessels (2017) offer six motives to explain why firms form CBMAs: (1) improving the performance of the target and/or the focal company to reduce costs and/or improve margins; (2) consolidating to remove access capacity from an industry to extend the life of a maturing industry; (3) creating and/or accelerating market access for the target's and/or the acquirer's products, that is, acquiring companies with innovative products that have difficulty reaching their potential on their own or to expand market size for both the acquiring and the acquired firm; (4) building skills or technologies more rapidly and/or at lower cost than these can be built in-house, that is, to enhance product lines or technologies more rapidly than these can be done in-house; (5) exploiting a business's industry-specific scalability to share platforms with smaller and less capable competitors; and (6) helping develop winning businesses to take advantage of its capabilities before competitors realize its potential. Contractor et al. (2010) expand on Goedhart et al.'s (2017) overview and suggest that CBMAs are direct responses to today's growing need for rapid and fluid value generation that can be appropriated across the continuously broadening geographic networks of internationalizing enterprises. They indicate that growing complexity in products today require ever-broadening knowledge inputs, many of which are outside the firm's internal capabilities. These knowledge inputs can be accessed by contracts (alliances, joint ventures) or via outright purchases of knowledge accumulation clusters thru mergers with, or acquisitions of, other enterprises that possess desired knowledge inputs. They reason that because the marginal costs of alliances and other kinds of partnerships (increased costs of coordination with the partner, greater complexity in managing operations, blending of corporate cultures) are often greater than those in outright purchases through CBMAs, EMMNEs have been turning to them as mechanisms with which to internalize and appropriate value generation capabilities. Contractor et al. argue that these arrangements give firms the opportunity for rapid organizational and geographic reconfiguration and dynamic creation of new competitive advantages, such that through CBMAs the firm can become simultaneously an explorer (a knowledge seeker) and an exploiter (a cost reducer) while also growing into an entity that is skilled in managing global supply chain and innovation networks and improve its allocation and coordination efficiencies.

\section{How do CBMAs foster Knowledge and Capability Transfers?}

The Roles of Social Communities, Culture, and Absorptive Capacity in Knowledge Transfers 
Verbeke (2010) views firms as social communities and argues that CBMAs are formed to heighten innovation capacities through knowledge transfers. He suggests that when CBAs are formed, two social communities with often different dominant logics combine. Imposing the acquiring firm's dominant logic is dysfunctional; thus, the combining firms need to focus on social community building through mutual adaptation and soft-bundling mechanisms to foster intra-MNE knowledge flows within the newlyestablished social community. Mutual adjustment and institutionalizing a jointly-derived dominant logic are essential in facilitating knowledge transfers and innovation capacity building through asset and capability bundling in the longer term. Verbeke offers that successful acquisitions are those that are able to effectively bundle desirable assets and capabilities of the adjoining firms and shed the undesirable assets and capabilities of the acquired firm. In this context, CBMA success is a function of both exploration (innovation capacity building through knowledge transfer) and exploitation (bundling ambidextrous knowledge bases). In a similar vein, Birkinshaw, Bresman, and Hakanson (2000) feel that CBMA success is a function of achieving operational synergies and achieving human integration, both leading to cultural convergence and mutual respect. Achieving operational synergies is built upon the success of the human integration that has been achieved, which in turn, leads to greater interdependencies between the acquired and the acquiring firms. These two synchronous integration processes foster knowledge transfers and knowledge combinations. Building on Birkinshaw et al. (2000) and Verbeke (2010), Zander and Zander (2010) propose that new knowledge is generated in CBMAs through continuous re-combinations of social communities who share identities and global knowledge reservoirs, knowledge brokerage and orchestration, and global inculcation of values. They suggest that challenges associated with knowledge transfers, i.e., those due to geographic and cultural distance, may be overcome through a gradual building of social communities (sharing a sense of common identity and belonging) where individuals can engage in smoother knowledge exchange and knowledge transfer to occur. They argue that these can help surmount the inter-cultural problems that are typical in CBMAs.

Bjorkman, Stahl, and Vaara (2007) link capability transfers via CBMAs to cultural similarities and differences between the acquirer and the acquired firm. Specifically, they argue that cultural similarities (differences) in the values, beliefs, and practices of the acquiring and the acquired firm facilitate (or hinder) capability transfer through their impacts on capability complementarity between the acquiring and the acquired firm, social integration that these two firms are able to achieve, and the potential absorptive capacity of these firms. They argue that this process may be moderated by the effective use of social integration mechanisms and the degree of operational integration of the acquired firm into the new entity. They reason that the relationship between cultural differences and CBMA performance can be more complex, however, since such variables as the redeployment of complementary resources between the acquiring and the acquired firm may moderate that relationship. In addition, access to complementary 
capabilities might mediate the effect of cultural similarities (differences) on post-CBMA capability transfers and the degree of social integration or the ability of the two organizations involved in the CBMA to absorb capabilities from each other. Bjorkman et al. stress that CBMAs are ultimately about value creation and value appropriation resulting from complementary capability combinations that cannot easily be duplicated by other entities so that the acquirer earns (or has the potential to earn) abnormal returns from the CBMA. Bjorkman et al. find that capability transfers lead to a transformation and/or exploitation of knowledge by the recipient firm that combines the transferred knowledge with its existing capabilities. They show that higher degrees of social integration (creation of a shared identity, shared vision, and shared pursuit of projects), operational integration, and absorptive capacities present in both firms foster greater capability transfers. Schweiger and Goulet (2005) underscore Bjorkman et al.'s arguments and add that deep cultural learning interventions by the management of the merging teams ease the postacquisition integration process. In the same vein, Sarala and Vaara (2010) propose that both cultural differences (crossvergence) and cultural integration (convergence) will positively influence knowledge transfers in CBMAs. An important part of MNE competitive advantage is the MNE's ability to access the unique stocks of knowledge that resides in geographically dispersed units around the globe and to combine these through organizing and integrating them into more useful knowledge forms that will support sustaining its competitive advantage. By re-contextualizing, reapplying and redeploying the transferred knowledge in new contexts, the recipient MNE will be able to strengthen its global competitive advantage. Thus, knowledge transfers through CBMAs are essential to the MNE's global growth.

\section{Reverse Knowledge Transfers (RKT) in EMMNEs via CBMAs}

On the one hand, EMMNEs' knowledge and capability transfers through CBMAs have been much more challenging than CBMA transfers by developed economy firms. This is because EMMNEs have not historically possessed the required competencies, such as globally-known brand names, marketing prowess, proprietary technology or state of the art manufacturing facilities, nor have they possessed the value generation capabilities, such as, transforming technologies into products efficiently and effectively through innovation, when compared to their developed country counterparts. They have also traditionally suffered from liabilities of foreignness in markets abroad. On the other hand, EMMNEs have been developing other capabilities that are superior to their developed country counterparts, such as learning agility, higher degrees of entrepreneurship, and surviving in institutional voids in their home markets that are now helping them become more globally-competitive enterprises. We find that they are now engaging in upgrading their weak competencies and blending these with their stronger ones through reverse 
knowledge transfers (RKT) to catch-up to their developed country counterparts (Madhok and Keyhani 2012).

The conceptual backdrop of this interplay is provided by the "springboard perspective" (Luo and Tung 2007) and the "LLL framework" (Mathews 2006) which propose that EMMNEs pursue CBMAs to gain access to the knowledge-based assets and capabilities that reside in their more competent foreign affiliates to overcome disadvantages and to appropriate this knowledge throughout their networks. Thus RKT, that is, accessing, internalizing, and appropriating knowledge from foreign affiliates, helps EMMNEs to spring forward and catch up to their developed country counterparts rapidly and more effectively.

This view is underscored in the literature in several studies, For example, Nair, Demirbag and Mellahi (2015) find that their hunger for capability ownership persuade Indian parent firms to initiate RKT to overcome the disadvantages they feel they have in complex knowledge types. Their findings show specifically that higher levels of collaboration between the Indian parent firms and their overseas subsidiaries facilitate RKT to the Indian parents and that this effect is more prominent in high-tech and knowledge-intensive industries. Subsidiaries located in host countries with higher degrees of competitiveness when compared to India and those that make specialized contributions give more toward the RKT. These subsidiaries help transform the country-location-specific assets into ownership advantages for the EMMNE's entire network making it more globally competitive. Organizational and knowledge characteristics and the nature of the relationships between the source and the recipient units facilitate (or sometimes hinder) the RKT process. Their findings show specifically that Indian MNEs are interested in the specialized capabilities residing in their specialized contributor subsidiaries, such as innovation capabilities, to overcome their liabilities of emergingness (Madhok and Keyhani 2015). They also want to tap into the industrial clusters that their acquired affiliates are parts of to utilize the benefits from local networks and the operational synergies that may result from these to help them lay global footprints. In essence, Nair et al.s (2015) findings indicate that Indian MNEs seek complementary diamonds; that is, intangible assets in host countries that have specific advantages that they can derive global competitiveness from. They also find that greater collaboration between the parent and the affiliated units yields positive effects on RKT; i.e., they are able to acquire the specific coordination skills to carry out the RKT. In sum, a collaborative culture in the Indian MNEs and their affiliates appears to foster knowledge creation through knowledge exchanges, helping them to "springboard" into higher levels of learning, especially complex knowledge and capabilities they traditionally do not possess. RKTs in these cases help them overcome unbalanced diamonds (Rugman and Verbeke 1993).

In a follow-up study, Nair, Demirbag and Mellahi (2016) show that higher gains from RKTs by Indian EMMNEs are achieved through the interplay of at least three ingredients, i.e., the level of absorptive 
capacity (AC) that is present in the acquiring firm; the capabilities the firm perceives in the subsidiary it is about to acquire; and the relevance of the knowledge it wants to transfer. Nair et al. show that knowledge relevance plays a more decisive role in certain knowledge flows (technical, marketing and management know-how) than in other functions; in these, knowledge flows are significant vehicles that springboard the firm to acquire strategic assets and continue to learn from overseas markets. Nair et al.'s work also reveals that a knowledge transfer-conducive learning environment and a knowledge infrastructure that fosters distributive learning present in the acquiring MNE are important elements of RKTs in Indian internationalizing enterprises.

In a third study, Nair, Demirbag, Mellahi, and Pillai (2017) examine the effects of certain knowledge attributes of the knowledge to be transferred, such as knowledge tacitness, on the effectiveness of the RKT process. Their findings indicate that the extent of the knowledge transferred increases as the level of knowledge tacitness increases, most likely as a result of its importance in springboarding the EMMNE into higher levels of competitiveness. They find that the degree of collaboration and social capital involved in that collaboration (shared vision, shared identity, mutual trust, mutual respect, commitment to joint goals) also positively influence the extent and the integration of the transferred knowledge with the existing knowledge base of the acquiring firm, most likely because (tacit) knowledge is transferred most effectively through shared understanding between the transferring entities. Nair et al. underscore the thesis that EMMNEs seek knowledge that is focused on the accelerated learning from their overseas subsidiaries, and that the more EM parent units engage in RKT, the more benefits they will accrue.

Ai and Tan (2017) corroborate Nair et al.'s (2015, 2016, and 2017) and Bjorkman et al.'s (2007) findings. They find that in the Chinese firms in their sample, the presence of knowledge structure elements, i.e., the prior related knowledge already present in the acquiring firm, the firm's previous internationalization experience, its current R\&D capabilities, and prior knowledge of the target firm and its capabilities, along with the presence or building of a knowledge-transfer-conducive environment (AC) in the acquiring firm lead to positive knowledge transfer outcomes, such as better social and operational integration of the two firms. They find that these factors contribute positively to post-acquisition RKT by directly improving the acquirer's AC and building a harmonious climate that helps facilitate knowledge transfers.

\section{Knowledge Exchange Process Phases and Assuring Post-acquisition CBMA Success}

Research that has examined CBMAs and their success outcomes can be traced to the Haspeglagh and Jemison (1991) typology in which mergers and acquisitions were viewed to be evaluated along the merging firms' competing needs for strategic interdependence (SI) and organizational autonomy (OA) after the CBMA has been consummated. Graebner (2004) and Zaheer et al. (2013) offered similar 
typologies later, but in all of these the competing dimensions spoke essentially to whether value would be created (exploration) or captured (exploitation) through the focal CBMA. In essence, the SI dimension explains how interdependent merging firms should be in terms of their capability transfers and resource sharing, and the OA dimension explains the extent to which a firm's culture and embedded strategic capabilities are maintained or dissolved (whether a single culture is imposed on the acquired firm or tolerance for multiculturalism is maintained). For instance, Angwin and Meadows (2015) propose that one can place a given CBMA into one of four possible cells that result from the interplay between these two dimensions: de-culturation, preservation, absorption (assimilation), and symbiosis (symbiotic integration where firm boundaries dissolve).

Quah and Young (2005) offer an evolutionary perspective on CBMA success. They argue that to assure CBMA success, the post-acquisition process should be managed in phases, ie, pre-acquisition, slow absorption, active absorption, and total absorption, each phase followed through with defined objectives and managerial actions. They propose that several factors should influence post-acquisition outcomes as the CBMA travels through these phases, i.e., the level of integration desired; post-acquisition changes planned; the timing of these changes; cultural influences; and employee behavior in the acquired firm. CBMA firms should measure post-acquisition success along both performance-related (hard) and cultural-adaption-related (soft) metrics and recognize that value creation and/or value appropriation may not always be realized.

Junni, Sarala, Tarba, and Weber (2015) offer a resource-based-view (RBV) explanation to CBMA success outcomes. They propose that CBMA success is primarily a function of how resources are transferred and deployed between the combined firms in the post-acquisition integration process. They describe this through strategic agility, a dynamic capability of the organization to renew itself and to stay flexible without sacrificing efficiency; that is, they view post-CBMA integration as a dynamic capability of the firm by which resource renewal in the acquisition takes place. This is accomplished in an envelope composed of operational and sociological integration processes; the aim of the post-CBMA integration is to facilitate knowledge transfer between the acquisition firms to create synergistic value. They posit that, strategic sensitivity, resource fluidity, and collective commitment, constituent elements of strategic agility, together enable the firm to take on newer strategic commitments while remaining nimble and flexible. In essence, they view the post-CBMA knowledge transfer and integration process as composed of strategic sensitivity (identifying targets that are knowledge-complementary and/or possess asymmetric knowledge with the acquiring firm), resource fluidity (identifying targets that will help implement a high degree of structural integration with the parent firm), and collective commitment (identifying targets that will accept the acquirer's culture, acquirer's acceptance of the target's culture, and presence of cultural learning in 
the merged enterprise). They propose that these will, in turn, lead to higher levels of post-acquisition performance. Their reasoning is based on the notion that strategically agile firms are those who are able to create dynamic portfolios of products, services, and business models to outcompete relevant competitors by integrating knowledge from around the world to fuel continuous innovations. They view strategic agility as a dynamic process that functions as a coordinating mechanism in support of knowledge transfer where complementary knowledge bases of the acquirer and the target firms and positive attitudes toward cultural integration enhance mutual knowledge transfer.

\section{Human Resource Issues in CBMAs}

Aguilera and Dencker (2004) propose that HRM can play a significant role in the value-adding process in CBMAs in terms of resource configurations, processes and values that reflect the particular national context and strategic fit situation because CBMAs can be highly emotional events for the employees of the acquired and the acquiring firms resulting in strong affective reactions that may affect work-related outcomes. They examine the effects of managerial communication, managerial support, and three cultural dimensions of Hofstede's framework. They find from their cross-country sample that all five of these factors have significant direct effects on employees' work-related outcomes, such as turnover intention and behaviors, such as active vs passive resistance to change. Wilkinson, Wood, and Demirbag (2014) corroborate this finding in a special issue of Human Resource Management dedicated to HRM issues in CBMAs and propose that firms adapt their HRM policies to the specific contexts in which they operate; that is, after CBMAs are formed, firm-level practices may at least partially isomorph their practices in line with national level institutions and/or local cultural specificities. More recent work has suggested that, in general MNEs will tend to align their practices in line with country of domicile realities, at least in some instances to benefit from local complementarities (Brewster et al. 2016; Demirbag, Tatoglu, Glaister, 2016; Gomes et al., 2015). In other words, if firms enter particular countries, they are, in many instances, at least partially enticed by specific contextual features at firm level and/or across the wider economy, and, hence, may have a vested interest in the status quo. This is not to suggest that EMNEs may not adopt specific practices that are relatively novel. For example, within tropical Africa, owing to country of origin pressures and in the interests of internal organizational communicative ease, many Chinese MNEs have chosen to import even unskilled labor from their country of origin. Again, there may be a range of more subtle changes that are implemented, as will become apparent from some of the papers in this volume.

\section{FDI Protectionism, FDI Quality, and CBMA Activity}


It is unclear currently whether and the extent to which the populist protectionist drift in the US, and to an extent, in other countries, will translate into more comprehensive protectionist measures against FDI, and by extension against CBMAs. A number of high profile controversies, most notably the abortive Dubai Ports World takeover of six US ports, has provided some indication of future barriers against high profile acquisitions abroad (Cumming et al. 2017). Such incidents may have a chilling effect on behavior, altering the strategic focus of EMMNEs toward more hospitable industries. Hence, although this special issue focuses on actual EMMNEs' CBMA events and their aftermath, it is worth considering that their occurrence and post-merger strategies may be partially framed by opportunities closed off elsewhere. Again, in looking at FDI, this collection primarily focuses on quality acquisitions, where the primary focus is on implementing some or other changes to organizational processes in the target and/or enhancing those acquired capabilities that are complementary to existing ones. However, there are a large number of acquisitions that take place where the target firms' market presence and resources are less important than the opportunities it may afford to move money offshore and/or to reduce tax liabilities (Jones and Temouri 2016). EMMNEs from some countries of origin, for example, Russia and some of the Gulf autocracies, may be particularly prone to this type of behavior. For target firms and host countries, such investments may provide a valuable source of foreign capital, but they may corrupt host country institutions and have little or negative effects in terms of promoting competitiveness (DeBacker et al. 2015). In short, in considering the ecosystem of EMMNE CBMAs, it should be recognized that the quality end of the spectrum is only a proportion of overall activity. 
Table 1. Overview of the Contributions of the Papers Selected for this Special Issue

\begin{tabular}{|c|c|c|c|c|}
\hline Authors & Focus & Major findings & $\begin{array}{l}\text { Type of } \\
\text { Research }\end{array}$ & Future research directions \\
\hline $\begin{array}{l}\text { Fu, Sen and } \\
\text { Ghauri }\end{array}$ & $\begin{array}{l}\text { Reverse knowledge } \\
\text { transfer and post- } \\
\text { acquisition integration } \\
\text { process } \\
\begin{array}{ll}\text { - } & \text { Reverse } \\
& \text { learning } \\
\text { - } & \text { Knowledge } \\
& \text { sharing }\end{array}\end{array}$ & $\begin{array}{l}\text { This paper proposes a capability } \\
\text { acquisition model consisting of reverse } \\
\text { learning mechanism, a multi-level hub } \\
\text { and spoke type of knowledge sharing } \\
\text { mechanism and integration mechanism. } \\
\text { The paper identifies a reverse innovation } \\
\text { and capability upgrading mechanism. It } \\
\text { argues that in the case firms, acquired } \\
\text { capabilities from developed markets } \\
\text { improved economic benefit and } \\
\text { management ability, and facilitated the } \\
\text { knowledge sharing and integration in } \\
\text { these companies. }\end{array}$ & $\begin{array}{l}\text { Case Study } \\
\text { of Huawei } \\
\text { and ZTE }\end{array}$ & $\begin{array}{l}\text { Comparison with EMNEs' } \\
\text { experiences in developing countries to } \\
\text { compare with their learning } \\
\text { mechanisms with those of EMNEs } \\
\text { investing in DMs. } \\
\text { Different types of subsidiaries may } \\
\text { have different experiments therefore } \\
\text { comparison of acquired subsidiaries } \\
\text { with those established through a } \\
\text { greenfield investment is another } \\
\text { avenue for future research. }\end{array}$ \\
\hline $\begin{array}{l}\text { de Olivera and } \\
\text { Rottig }\end{array}$ & $\begin{array}{l}\text { Home institutional } \\
\text { environment and post } \\
\text { M\&A integration } \\
\text { approach of a Chinese } \\
\text { MNE }\end{array}$ & $\begin{array}{l}\text { Context specific supporting partnership } \\
\text { approach is an available option for } \\
\text { Chinese MNEs. }\end{array}$ & $\begin{array}{l}\text { Case study } \\
\text { of Preh } \\
\text { GmbH } \\
\text { acquisition } \\
\text { by Joyson } \\
\text { Ltd }\end{array}$ & $\begin{array}{l}\text { The paper suggest more studies with } \\
\text { comparative and quantitative focus } \\
\text { aiming to examine full integration and } \\
\text { performance as well as supporting } \\
\text { partnering and performance } \\
\text { relationships. } \\
\text { Exploration of semi-institutional } \\
\text { environment in different country } \\
\text { contexts and impact on EMNEs' } \\
\text { market entry and post-acquisition } \\
\text { strategies. }\end{array}$ \\
\hline $\begin{array}{l}\text { Ilhan-Nas, Okan, } \\
\text { Tatoglu, Demirbag } \\
\text { and Glaister }\end{array}$ & $\begin{array}{l}\text { Ownership } \\
\text { concentration in } \\
\text { EMNEs, institutional } \\
\text { distance, and } \\
\text { internationalization and } \\
\text { equity ownership in } \\
\text { foreign subsidiaries }\end{array}$ & $\begin{array}{l}\text { Institutional differences moderate the link } \\
\text { between ownership concentration and } \\
\text { ownership strategies of EMNEs' in } \\
\text { internationalization. }\end{array}$ & $\begin{array}{l}\text { Survey of } \\
355 \text { foreign } \\
\text { subsidiaries } \\
\text { of } 68 \\
\text { Turkish } \\
\text { MNEs }\end{array}$ & $\begin{array}{l}\text { The focus should be more on board } \\
\text { structure, top management team } \\
\text { characteristics including tolerance for } \\
\text { risk and personal attributes of team } \\
\text { members as these play significant role } \\
\text { in post-acquisition strategies. }\end{array}$ \\
\hline
\end{tabular}




\begin{tabular}{|c|c|c|c|c|}
\hline $\begin{array}{l}\text { Patel, Sinha and } \\
\text { Bhanugopan }\end{array}$ & $\begin{array}{l}\text { Transfer of HRM } \\
\text { practices in Indian IT } \\
\text { MNEs with } \\
\text { subsidiaries in } \\
\text { Australia }\end{array}$ & $\begin{array}{l}\text { Indian IT MNEs adopt a hybrid approach } \\
\text { in HRM practice transfer from HQ with } \\
\text { locally responsive HRM practices to suit } \\
\text { their Australian subsidiary context. In } \\
\text { doing so, they mainly combine their } \\
\text { parent country HR practices with some } \\
\text { local practices to diffuse these practices in } \\
\text { their Australian subsidiaries. }\end{array}$ & $\begin{array}{l}\text { Survey of } 15 \\
\text { Indian IT } \\
\text { MNEs with } \\
\text { subsidiaries } \\
\text { in Australia }\end{array}$ & $\begin{array}{l}\text { Examining EMNE's HRM practice } \\
\text { transfers from non IT industries. } \\
\text { A more focused approach to transfer } \\
\text { of individual HRM practice transfer as } \\
\text { well as the process of HR diffusion, } \\
\text { mechanisms used transfer of practices } \\
\text { from EMNEs' HQs to their } \\
\text { subsidiaries. } \\
\text { Examining the role of HRM practice } \\
\text { in post-acquisition integration and } \\
\text { subsidiary performance. }\end{array}$ \\
\hline $\begin{array}{l}\text { Ozcan, Coronado } \\
\text { Mondragon and } \\
\text { Harindranath }\end{array}$ & $\begin{array}{l}\text { EMNEs' strategic entry } \\
\text { to DC markets and } \\
\text { operational integration }\end{array}$ & $\begin{array}{l}\text { The levels of integration emerge to be } \\
\text { industry and context specific. The sample } \\
\text { case studies reveal that EMNEs } \\
\text { successfully integrated their UK } \\
\text { operations through supply chain networks } \\
\text { and IT infrastructure. The nature of } \\
\text { integration varies among these three } \\
\text { firms. }\end{array}$ & $\begin{array}{l}\text { Case Study } \\
\text { of Cemex, } \\
\text { Beko and } \\
\text { Tata Steel in } \\
\text { the UK }\end{array}$ & $\begin{array}{l}\text { The future research should be more } \\
\text { directed toward protectionist } \\
\text { tendencies of developed countries and } \\
\text { post-acquisition strategies of EMNEs }\end{array}$ \\
\hline $\begin{array}{l}\text { Batsakis, Wood, } \\
\text { Azar and Singh }\end{array}$ & $\begin{array}{l}\text { Relationship between } \\
\text { international } \\
\text { diversification and } \\
\text { performance of } \\
\text { EMNEs in the post- } \\
\text { acquisition period. }\end{array}$ & $\begin{array}{l}\text { Acquisition events positively affect } \\
\text { international diversification and } \\
\text { performance relationship. The acquisition } \\
\text { size however, negatively moderates this } \\
\text { relationship. Business group affiliations } \\
\text { have positive moderating impact on } \\
\text { international diversification and } \\
\text { performance in the post-acquisition } \\
\text { period. }\end{array}$ & $\begin{array}{l}\text { Survey of } \\
164 \text { publicly } \\
\text { listed Indian } \\
\text { MNEs }\end{array}$ & $\begin{array}{l}\text { How the relationship between } \\
\text { international diversification and } \\
\text { performance in the post-acquisition } \\
\text { period is moderated by characteristics } \\
\text { of the acquirer firm. } \\
\text { How the country level characteristics } \\
\text { influence the formerly-mentioned } \\
\text { relationship. }\end{array}$ \\
\hline $\begin{array}{l}\text { Ibeh and } \\
\text { Makhmadshoev }\end{array}$ & $\begin{array}{l}\text { Nascent African } \\
\text { MNEs' approach to } \\
\text { integrate the intra- } \\
\text { regional acquisitions }\end{array}$ & $\begin{array}{l}\text { African MNEs examined in this paper } \\
\text { adopted a control enabling absorptive } \\
\text { type integration approach. } \\
\text { This paper also reveals a strong } \\
\text { connection between acquirers' resource } \\
\text { position and post-acquisition integration } \\
\text { approach adopted. The paper also } \\
\text { highlights the potential impact of }\end{array}$ & $\begin{array}{l}\text { Case Study } \\
\text { of } 2 \text { African } \\
\text { MNEs - } \\
\text { financial } \\
\text { service } \\
\text { groups }\end{array}$ & $\begin{array}{l}\text { More data for testing relationships } \\
\text { proposed in this paper including } \\
\text { quantitative research designs. } \\
\text { More substantive research to explicate } \\
\text { the relationship between integration } \\
\text { approach and post-acquisition } \\
\text { performance. }\end{array}$ \\
\hline
\end{tabular}




\begin{tabular}{|c|c|c|c|c|}
\hline & & $\begin{array}{l}\text { institutional similarity on the type of } \\
\text { integration adopted by these nascent } \\
\text { African MNEs }\end{array}$ & & \\
\hline $\begin{array}{l}\text { Cooke, Wu, Zhou, } \\
\text { Zhong and Wang }\end{array}$ & $\begin{array}{l}\text { Post-acquisition } \\
\text { challenges that Chinese } \\
\text { MNEs' may encounter- } \\
\text { implications for } \\
\text { capability building }\end{array}$ & $\begin{array}{l}\text { This paper develops proposal regarding } \\
\text { how to manage formal and informal } \\
\text { institutional actors. In doing so, it takes a } \\
\text { broader view, and integrates industrial } \\
\text { relations literature with the strategic HRM } \\
\text { literature. It particularly focuses on cross- } \\
\text { cultural management issues, talent } \\
\text { management and workplace diversity. }\end{array}$ & $\begin{array}{l}\text { Literature } \\
\text { review }\end{array}$ & $\begin{array}{l}\text { Future research may examine HRM in } \\
\text { Chinese MNEs in the context of cross } \\
\text { border M\&As with a special attention } \\
\text { to multivariate factors affecting } \\
\text { Chinese MNEs' strategy and } \\
\text { performance. Broader impact of these } \\
\text { factors on employees and other } \\
\text { stakeholders may also be another } \\
\text { future research on Chinese MNEs' } \\
\text { acquisitions. } \\
\text { Power relationship and Chinese MNEs } \\
\text { is another dimension for further } \\
\text { research- i.e., how Chinese MNEs } \\
\text { develop and deploy various sources of } \\
\text { power to their advantage? }\end{array}$ \\
\hline He and Zhang & $\begin{array}{l}\text { Home country } \\
\text { institutional image and } \\
\text { acquisition completion } \\
\text { by EMNEs }\end{array}$ & $\begin{array}{l}\text { The institutional image effect exists for } \\
\text { EMNEs' overseas takeovers, and } \\
\text { acquisition completion is negatively } \\
\text { associated with their country image } \\
\text { proxied by institutional quality. EMNEs } \\
\text { with inward internationalization } \\
\text { experience do better at acquisition } \\
\text { completions and this type of experience } \\
\text { reduces the liability of EMNEs' home } \\
\text { institutions image. Acquisition } \\
\text { completion is more likely when there is a } \\
\text { lower institutional distance between the } \\
\text { acquirer and the acquiree. }\end{array}$ & $\begin{array}{l}\text { Survey of } \\
13259 \\
\text { acquisitions } \\
\text { by } \\
\text { EMMNEs }\end{array}$ & $\begin{array}{l}\text { Extending a similar design to include } \\
\text { acquisitions by other EMNEs. } \\
\text { Examining links between institutions, } \\
\text { M\&As and performance in a } \\
\text { comparative study. } \\
\text { Using other forms of collaborations as } \\
\text { a measure of international experience } \\
\text { in an extended model. }\end{array}$ \\
\hline $\begin{array}{l}\text { Han, Liu, Xia and } \\
\text { Gao }\end{array}$ & $\begin{array}{l}\text { The role of home } \\
\text { country financial and } \\
\text { non-financial support } \\
\text { and interstate relations } \\
\text { on overseas subsidiary }\end{array}$ & $\begin{array}{l}\text { Home government non-financial support } \\
\text { enhances Chinese MNEs' overseas } \\
\text { subsidiary performance. } \\
\text { Financial support by Chinese government } \\
\text { however, does not have a direct }\end{array}$ & $\begin{array}{l}\text { Survey of } \\
148 \text { Chinese } \\
\text { MNEs }\end{array}$ & $\begin{array}{l}\text { Use of objective data to test impact of } \\
\text { home country government financial } \\
\text { and non-financial support on post- } \\
\text { acquisition performance. } \\
\text { Use of more fine grained constructs to }\end{array}$ \\
\hline
\end{tabular}




\begin{tabular}{|c|c|c|c|c|}
\hline & $\begin{array}{l}\text { performance of } \\
\text { Chinese MNEs }\end{array}$ & $\begin{array}{l}\text { performance enhancing impact on } \\
\text { Chinese MNEs' overseas subsidiary } \\
\text { performance. Interstate political } \\
\text { relations, for the Chinese MNEs, serve as } \\
\text { a promoting device which augments the } \\
\text { positive link between non-financial } \\
\text { support and Chinese MNEs' overseas } \\
\text { subsidiary performance. }\end{array}$ & & $\begin{array}{l}\text { test relations between interstate co- } \\
\text { operations and conflict, percentage of } \\
\text { state owned shares on post-acquisition } \\
\text { integration strategy and performance. }\end{array}$ \\
\hline $\begin{array}{l}\text { Park, Meglio, } \\
\text { Bauer, and Tarba }\end{array}$ & $\begin{array}{l}\text { Transformation of an } \\
\text { EMNE making } \\
\text { multiple acquisitions } \\
\text { with special reference } \\
\text { to post acquisition } \\
\text { integration and } \\
\text { organizational } \\
\text { dynamics }\end{array}$ & $\begin{array}{l}\text { Types of acquisitions and post-acquisition } \\
\text { integration approaches changed overtime } \\
\text { in this longitudinal study. These changes } \\
\text { cumulatively transformed the } \\
\text { organizational identity of this large global } \\
\text { logistics firm in the Middle East. }\end{array}$ & $\begin{array}{l}\text { Longitudinal } \\
\text { study of a } \\
\text { global } \\
\text { logistics } \\
\text { MNE from } \\
\text { the Middle } \\
\text { East. The } \\
\text { firm made } \\
\text { more than } \\
150 \\
\text { acquisition } \\
\text { deals over } \\
20 \text { years. }\end{array}$ & $\begin{array}{l}\text { Future research may consider } \\
\text { examining multiple cases for } \\
\text { examining organizational dynamics } \\
\text { and identity in post-acquisition } \\
\text { integration period. } \\
\text { The current paper does not include } \\
\text { target's perspective in this study. } \\
\text { Adding target perspective to the } \\
\text { examination may further enhance our } \\
\text { understanding of organizational } \\
\text { dynamics and identity related aspects } \\
\text { of post-acquisition integration. How } \\
\text { metamorphosis of acquiring firms } \\
\text { occurs in different contexts and the } \\
\text { role of knowledge transfer? }\end{array}$ \\
\hline $\begin{array}{l}\text { Kong, Ciabuschi } \\
\text { and Martin }\end{array}$ & $\begin{array}{l}\text { The effects of } \\
\text { expatriate managers' } \\
\text { relationships within } \\
\text { EMNEs on reverse } \\
\text { knowledge transfer }\end{array}$ & $\begin{array}{l}\text { Subsidiary willingness to transfer } \\
\text { knowledge has positive impact on reverse } \\
\text { knowledge transfer (RKT) from overseas } \\
\text { subsidiaries to home country units in } \\
\text { EMNEs. Expatriate managers foster both } \\
\text { relationship with local managers and RKT } \\
\text { to home units and expatriate managers' } \\
\text { relationships with local managers } \\
\text { positively affect subsidiary willingness to } \\
\text { transfer knowledge. Quality of expatriate } \\
\text { managers' relationships with HQ however } \\
\text { does not contribute to subsidiary } \\
\text { willingness for RKT. }\end{array}$ & $\begin{array}{l}\text { Survey of } \\
128 \\
\text { Subsidiaries } \\
\text { of } 73 \\
\text { Chinese } \\
\text { MNEs }\end{array}$ & $\begin{array}{l}\text { Exploration of incentive mechanisms } \\
\text { for expatriate managers to develop } \\
\text { high quality relationships with local } \\
\text { managers and stakeholders in the post- } \\
\text { acquisition period. } \\
\text { The extent of knowledge transfer from } \\
\text { acquired subsidiaries to home units of } \\
\text { EMNEs and actual use of transferred } \\
\text { knowledge. }\end{array}$ \\
\hline
\end{tabular}




\begin{tabular}{|l|l|l|l|l|}
\hline Liu and Yu & $\begin{array}{l}\text { International } \\
\text { experience and host } \\
\text { country institutions } \\
\text { moderating impact on } \\
\text { establishment mode } \\
\text { choice by EMNEs }\end{array}$ & $\begin{array}{l}\text { Chinese firms; international experience } \\
\text { and the quality of host country institutions } \\
\text { moderate the effects of home institutions } \\
\text { development level on their overseas } \\
\text { subsidiary establishment mode. }\end{array}$ & $\begin{array}{l}\text { Survey of } \\
\text { 496 OFDI } \\
\text { projects by } \\
\text { 312 Chinese } \\
\text { MNEs }\end{array}$ & $\begin{array}{l}\text { Comparative study of subsidiary } \\
\text { performance for different } \\
\text { establishment modes ad comparison } \\
\text { between EMNEs from different } \\
\text { emerging countries. }\end{array}$ \\
$\begin{array}{l}\text { What other resources and contextual } \\
\text { factors contribute EMNEs' subsidiary } \\
\text { establishment role and importance of } \\
\text { legal origin and linguistic proximity. }\end{array}$ \\
\hline
\end{tabular}




\section{Conclusions and Future Research Questions}

As an international business phenomenon, CBMAs have fascinated business scholars and managers for at least the last two decades. Many studies in this research stream explored the undercurrents of developed country internationalizing firms' spread into different geographies and institutional contexts, some via CBMAs. EMMNEs' internationalization through CBMAs has not received as much attention, however. While some work has addressed questions about EMMNEs' internationalization in general through focus on such questions as home- and host-market drivers of EMMNCs' expansion abroad, the firm- and country-specific competitive advantages they would employ as they internationalize, and the degree of their success in world markets, especially as they compete with Western rivals (Luo and Tung 2007; Cuervo-Cazzura and Genc 2008; Ramamurti and Singh 2009; Khanna and Palepu 2010; Ramamurti 2012; Jormanainen and Kovesnikov 2012; Madhok and Keyhani 2012, Yaprak, Yosun, and Cetindamar 2017), this literature failed to address the post-CBMA issues of EMMNCs. Specifically, this literature has not addressed questions surrounding forward and reverse knowledge transfer patterns from newly-entered markets post-merger or post-acquisition, corporate and national culture convergence and cross-vergence in post-acquisition settings, integration strategies pre- and post-mergers that will likely yield better value creation and appropriation, strategic agility during and after mergers and acquisitions, and culture's role in post-entry integration processes.

The collection of papers in this special issue addresses these questions, especially those that surround EMMNEs' post-market-entry presence in the markets they enter as they become more rooted in those markets through CBMAs (Table 1). The papers offer both theoretical insights and highlight a range of practical managerial challenges EMMNEs face post-CBMA integration. They also underscore the need for new research on EMMNEs and their changing roles in world commerce.

EMMNEs have become increasingly prominent on the world stage. In many instances, their international growth has been through CBMAs, especially recently. They have been aggressively moving up their value chains, "catching up" to their developed country counterparts, simultaneously exploiting their firm and country specific advantages and exploring innovation activities and learning to extract value from these activities (Emerging Market Multinationals Report 2017). They have been interacting with their new, (primarily) developed market institutional environments, molding them as they do so and being molded by them. As such, they have been helping alter the mix of actors and the strategic choices they make in their institutional environments and affecting the behavior of their peer firms. EMMNEs' CBMA activities have had consequences for their external environments along with altering their internal organizational mindsets and cultures. Thus, EMMNEs' CBMAs, as with other MAs, may be having both beneficial and deleterious effects in the contexts in which they are operating, such as shifting employment 
within their host markets or to offshore locations, loss of jobs for host country nationals, and intellectual asset stripping. These are questions for future research.

Other questions for future research include the challenges of managing greater workforce diversity postacquisition, of shifting organizational directions and internal culture to suit new priorities, and of navigating new political and contextual waters. Still others might include whether EMMNE CBMAs happen for different reasons than those created by their developed country counterparts; the effect of institutional and/or cultural dynamics on CBMA outcomes (are they mediating, a moderating, or an antecedent construct?); and, whether developed country MNEs lose value when they are acquired by EMMNEs. We hope that this volume will inspire new research on these questions.

\section{$\underline{\text { References }}$}

Aguilera, R.V, and Dencker, J.C. (2004), "The Role of Human Resource Management in Cross-border Mergers and Acquisitions", International Journal of Human Resource Management, 15 (8), 1355-1370.

Ahammad, M.F., Tarba, S.Y., Liu, Y. and Glaister, K.W. (2016). Knowledge transfer and cross-border acquisition performance: The impact of cultural distance and employee retention. International Business Review, 25(1), 66-75.

Ai, Q., and Tan, H. (2017). Acquirers' Prior Related Knowledge and Post-Acquisition Integration, Journal of Organizational Change Management, 30 (4), 647-662.

Angwin, D. N., and Meadows, M. (2015), New Integration Strategies for Post-Acquisition Management, Long Range Planning, 235-251.

Birkinshaw, J., Bresman, H., and Hakanson, L. (2000), Managing the Post-Acquisition Integration Process: How the Human Integration and Task Integration Processes Interact to Foster Value Creation, Journal of Management Studies, 37 (3), 395-425.

Bjorkman, I., Stahl, G.K., and Vaara, E. (2007), Cultural Differences and Capability Transfer in Crossborder Acquisitions: the Mediating Roles of Capability Complementarity, Absorptive Capacity, and Social Integration, Journal of International Business Studies, 38, 658-672.

Brandt, L. and Thun, E., (2016). Constructing a ladder for growth: policy, markets, and industrial upgrading in China. World Development, 80, 78-95.

Brewster, C., Brookes, M. and Wood, G. (2016). Are MNCs Norm Entrepreneurs or Followers? The Changing Relationship between Host Country Institutions and MNC HRM Practices, International Journal of Human Resource Management, 28 (12). 1690 - 1711.

Casanova, L. and Miroux, A. (2017). Emerging Market Multinationals Report: Emerging Multinationals in a Changing World, Emerging Markets Institute, Cornell University: SC Johnson College of Business.

Chattopadhyay, A., Batra, R., and Ozsomer, A. (2012), The New Emerging Market Multinationals: Four Strategies for Disrupting Markets and Building Brands, McGraw Hill: New York. 
Contractor, Farok J., Vikas Kumar, Sumit K. Kundu, and Torben Pedersen (2010), Reconceptualizing the Firm in a World of Outsourcing and Offshoring: The Organizational and Geographical Relocation of High-Value Company Functions”, Journal of Management Studies, 47, 8, 1417-1433.

Cumming, D., Wood, G., Filatotchev, I. and Wood, G. (2017). "Introducing Sovereign Wealth Funds", Cumming, D., Wood, G., Filatotchev, I. and Wood, G. (eds.), Oxford Handbook of Sovereign Wealth Funds. Oxford: Oxford University Press.

DeBacker, J., Heim, B.T. and Tran, A., (2015). Importing corruption culture from overseas: Evidence from corporate tax evasion in the United States. Journal of Financial Economics, 117(1), 122-138.

Demirbag, M., Tatoglu, E., and Wilkinson, A. (2016). Adoption of high performance work systems by local subsidiaries of developed country and Turkish MNEs and indigenous firms in Turkey, Human Resource Management, 55 (6), 1001-1024.

Demirbag, M., Tatoglu, E., and Glaister, K. (2010). Institutional and transaction cost determinants of Turkish MNEs' location choice, International Marketing Review, 27 (3), 272-294.

Demirbag, M., Tatoglu, E., and Glaister, K. (2009). Equity-based entry modes of emerging country multinationals: Lessons from Turkey, Journal of World Business, 44(4), 445-462.

Demirbag, M., Tatoglu, E., and Ng, C. (2007) Performance of mergers and acquisitions in pharmaceutical industry: a comparative perspective, Multinational Business Review, 15 (2), 41-61.

Demirbag, M., and Yaprak, A. (2015), Handbook of Emerging Market Multinational Corporations (Cheltenham, UK: Edward Elgar Publishing Co).

Graebner, M. (2004), Momentum and serendipity: how acquired leaders create value in the integration of technology firms, Strategic Management Journal, 25(8-9), 751-777,

Goedhart, M., Kohler, T., and Wessels, D. (2017), Six Types of Successful Acquisitions, McKinsey and Company Strategy and Corporate Finance (May).

Gomes, E., Sahadev, S., Glaister, A., and Demirbag, M. (2015). A comparison of international HRM practices by Indian and European MNEs: Evidence from Africa, International Journal of Human Resource Management, 26 (21), 2676-2700.

Jha, S., Dhanaraj, C. and Krishan, R., (2015). How does multinational R\&D evolve in emerging markets? Lausanne: IMD.

Jones, C. and Temouri, Y., (2016). The determinants of tax haven FDI. Journal of world Business, 51(2), 237-250.

Jormanainen, I., and Koveshnikov, A. (2012), International Activities of Emerging Market Firms: A critical assessment of research in top international management journals. Management International Review, 52, 691-725.

Junni, P., Sarala, R.M., Tarba, S.Y., and Weber, Y. (2015), The Role of Strategic Agility in Acquisitions, British Journal of Management, 26, 596-616.

Khanna, T., and Palepu, K. (2010). Winning in Emerging Markets: A Roadmap for Strategy and Execution. Harvard Business School Press. 
Luo, Y. and Tung, R.L., (2018). A general theory of springboard MNEs. Journal of International Business Studies, 49(2), 129-152.

Luo, Y., and Tung, R.L. (2007), International expansion of emerging market enterprises: A springboard perspective, Journal of International Business Studies, 38, 481-498.

Madhok, A., and Keyhani, M. (2012), Acquisitions as Entrepreneurship: Asymmetries, Opportunities, and the Internationalization of Multinationals from Emerging Economies, Global Strategy Journal, 2, 26-40.

McGuinness, M., Demirbag, M. and Bandara, S. (2013). Towards a multi-perspective model of reverse knowledge transfer in MNEs: A case study of Coats Plc., European Management Journal, 31(2), 179195.

Nair, S.R, Demirbag, M., and Mellahi, K. (2015), Reverse Knowledge Transfer from Overseas Acquisitions: A Survey of Indian MNEs, Management International Review, 55, 277-301.

Nair, S.R, Demirbag, M., and Mellahi, K. (2016), Reverse Knowledge Transfers in Emerging Market Multinationals: the Indian Context, International Business Review, 25, 152-164.

Nair, S.R, Demirbag, M., and Mellahi, K., and Pillai, K.G (2017), Do Parent Units Benefit from Reverse Knowledge Transfer? British Journal of Management, 28, 1-17.

Peng, M.W., Wang, D.Y. and Jiang, Y., (2008). An institution-based view of international business strategy: A focus on emerging economies. Journal of international business studies, 39(5): 920-936.

Quah, Q. and Young, S. (2005), Post-Acquisition Management: A Phases Approach for Cross-Border M\&As, European Journal of Management, 23 (1), 65-75.

Ramamurti, R., and Singh, J (2009). Emerging Multinationals in Emerging Markets._(Cambridge University Press: Cambridge, UK).

Sarala, R.M., and Vaara, E. (2010), Cultural Differences, Convergence, and Crossvergence as Explanations of Knowledge Transfer in International Acquisitions, Journal of International Business Studies, 41, 1365-1390.

Rodrik, D. (2016). An African growth miracle? Journal of African Economies, 27(1), 10-27.

Schweiger, D.M., and Goulet, P.K. (2005), Facilitating Acquisition Integration through Deep-Level Cultural Learning Interventions: A Longitudinal Field Experiment, Organization Studies, 26 (10), 14771499 .

Yiu, D.W., Lau, C. and Bruton, G.D., (2007). International venturing by emerging economy firms: The effects of firm capabilities, home country networks, and corporate entrepreneurship. Journal of International Business Studies, 38(4), 519-540.

Verbeke, A. (2010), International Acquisition Success: Social Community and Dominant Logic Dimensions, Journal of International Business Studies, 41, 38-46. 
Wilkinson, A., Wood, G., and Demirbag, M. (2014), Guest Editors' Introduction: People Management and Emerging Market Multinationals, Human Resource Management, 53, 6, 835-849.

Wood, G. 2015. "South African Multinationals in Africa: Growth and Controversy", Demirbag, M. and Yaprak, A. (eds.), Handbook of Emerging Market Multinational Corporations. Cheltenham: Edward Elgar

Zander, U., and Zander, L. (2010), Opening the Grey Box: Social Communities, Knowledge and Culture in Acquisitions, Journal of International Business Studies, 41, 27-37. 